\title{
CALCANEAL LOCALIZATION OF EXTRAHEPATIC HEPATOCELLULAR CARCINOMA PRESENTED WITH CHRONIC HINDFOOT PAIN
}

\author{
Lastella G. ${ }^{1}$, Avola E. ${ }^{1}$, Esposito A.2 \\ 1 - Università degli Studi di Milano. \\ 2 - Foundation IRCCS Ca' Granda Maggiore Policlinico Hospital, Radiology Department. Milan, Italy
}

$\mathrm{H}$ epatocellular carcinoma (HCC) metastasizes mainly in the liver through portal vein, only few patients report metastases in distant organs and bone is considered a rare site of HCC metastases. We report the case of a man with HCC, who presented with chronic right hindfoot pain, in which bone scintigraphy and computed tomography (CT) revealed a rare secondary calcaneus localization.

Case description. A 58-year-old man with multi-treated HCC, during a hepatological followup, complained of chronic right hindfoot pain, unresponsive to analgesic therapy. The bone scintigraphy shows focal hypercaptations in the right calcaneus and, less evidently, in the right tibia. CT showed multiple focal solid enhancing nodules in the tibial bone marrow, and a $3,5-\mathrm{cm}$ solid enhancing nodule in the calcaneal body, with cortical interruption and invasion of adjacent soft tissues. HCC calcaneal metastasis was confirmed through a biopsy.

Conclusion. In a patient with HCC and chronic hindfoot pain, with increase of alphafetoprotein levels, the possibility of a distant metastasis should be taken in account, as in our case, even though it is a rare cause.

Keywords: carcinoma, hepatocellular, liver neoplasms, bone neoplasms, neoplasm metastasis, tomography, radionuclide imaging.

Corresponding author: Lastella Giulia, e-mail: giulia.lastella@unimi.it

For citation: Lastella G., Avola E., Esposito A. Calcaneal localization of extrahepatic hepatocellular carcinoma presented with chronic hindfoot pain. REJR 2021; 11(2):238-242. DOI: 10.21569/22227415-2021-11-2-238-242.

Received: $\quad 15.03 .21 \quad$ Accepted: 12.05 .21

\section{КААЬКАНЕАЛЬНАЯ АОКААИЗАЦИЯ ВНЕПЕЧЁНОЧНОЙ ГЕПАТОЦЕААЮАЯРНОЙ КАРЦИНОМЫ, ПРОЯВАЯЮЩАЯСЯ ХРОНИЧЕСКОЙ БОАЬЮ B ЗААHEM OTAEАE CTOПЫ}

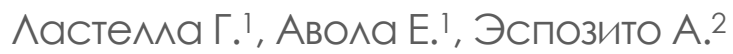 \\ 1 - Мияанский Университет degli Studi di Milano. \\ 2 - Foundation IRCCS, госпиталь Ca 'Granda Maggiore, отделение мучевой диагностики. Милан, Италия.
}

епатоцемююлярная карцинома (ГЦК) метастазирует главным образом в печень через воротную вену, и мишь у немногих пациентов встречаются отдаленные метастазы, а костная система считается редким местом дия метастазов ГЦК. Мы представляем кАинический случай пациента, мужчины с ГЦК, с хронической болью в правом заднем отделе стопы, у которого сцинтиграфия костей и компьютерная томография (КТ) выявили редкую вторичную мокализацию в области пяточной кости.

Материалы и методы. Во время обследования по основному заболеванию 58-цетний мужчина, после многократного мечения ГЦК, пожаловался на хроническую боль в правом зад 


\section{RUSSIAN ELECTRONIC JOURNAL OF RADIOLOGY}

нем отделе стопы, не реагирующую на анальгетическую терапию. Сцинтиграфия костей показала очаги гиперфиксации в правой пяточной кости и, в меньшей степени, в правой большеберцовой кости. КТ показала множественные солидные очаги, накапливающие контрастный препарат в обцасти костного мозга большеберцовой кости и солидный узел размером 3,5 см в теле пяточной кости с нарушением кортикальной пластинки и инвазией примежащих мягких тканей. Метастаз ГЦК в пяточную кость был подтвержден биопсией.

Заключение. У пациента с ГЦК и хронической болью в задней части стопы при повышении уровня альфа-фетопротеина следует учитывать возможность отдаленного метастазирования, как в нашем случае, несмотря на то, что это встречается очень редко.

Ключевые слова: карцинома, гепатоцемлюлярные, новообразования печени, местастазы кости, метастазы, томография, радионуклидная визуализация.

Контактный автор: Аастемла Джулия, e-mail: giulia.lastella@unimi.it

Для иитирования: Аастелла Г., Авола Е., Эспозито А. Кальканеальная локализаиия внепечёночной гепатоиеллюлярной карииномы, проявляюшаяся хронической болью в заднем отдеre cmonu. REJR 2021; 11(2):238-242. DOI: 10.21569/2222-7415-2021-11-2-238-242.
Статья получена:
15.03.21
Статья принята:
12.05 .21

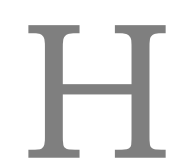

epatocellular carcinoma (HCC) is the most common liver malignancy and the fifth tumor in incidence, which usually affects patients with $\mathrm{HBV}$ and HCV chronic infection, alcoholic and nonalcoholic fatty liver disease [1]. Cirrhosis and chronic liver disease are considered the major risk factors, wherein multiple gene alterations result in high-risk nodules, which require screening with non-invasive imaging techniques and/or biopsy for an early detection of HCC [2, 3]. As for dissemination, unlike other carcinomas, HCC metastasizes mainly in the liver through portal vein; only few patients report metastasis in distant organs, such as lungs, adrenal glands and bones, in order of frequency $[4,5]$. Here we report the case of a 58-year-old man with multi-treated HCC, who presented with chronic right hindfoot pain. Bone scintigraphy and Computed Tomography (CT) revealed a rare secondary calcaneus localization.

\section{Case description.}

A 58-year-old man with multi-treated HCC, during a hepatological follow-up, complained of chronic right hindfoot pain, unresponsive to analgesic therapy. This discomfort was attributed to osteoarthritis and was underestimated, particularly because the patient also complained of chronic lumbar pain. Two months later, at a new follow up, alphafetoprotein levels demonstrated a rapid increase, from $556 \mu \mathrm{g} / \mathrm{L}$ to $884 \mu \mathrm{g} / \mathrm{L}$. As a disseminated $\mathrm{HCC}$, with possible multiple bone localizations was suspected, a bone scintigraphy was performed.
The bone scintigraphy was performed in our institution, using a double head gamma camera (Symbia, Siemens Medical Solutions, Erlangen, Germany), with a low-energy high resolution (LEHR) collimator and Technetium (99mTc) medronic acid injection. Some focal hypercaptations were found in the right calcaneus and, less evidently, in the right tibia (Fig. 1). No pathological hypercaptations were observed in the lumbar spine.

After these findings the patient underwent a CT of the right leg and foot, with a 64slice scanner (Somatom Sensation, Siemens AG, Forchheim, Germany), after an iodinebased contrast administration (Iopamidol, Iopamiro $370 \mathrm{mg} / \mathrm{ml}$, Bracco Imaging Italia s.r.1., Milan, Italy).

CT showed multiple focal solid enhancing nodules in the right middle and distal portions of the tibial bone marrow, with a heterogeneous enhancement (Fig. 2).

Moreover, a 3.5-cm solid enhancing nodule was observed in the medial side of the right calcaneal body, with cortical interruption and invasion of adjacent soft tissues (Fig. 3). HCC calcaneal metastasis was confirmed through a biopsy.

A systemic first-line immunotherapy with Sorafenib was then started. Due to drug intolerance, a second-line therapy with Cabozantin$i b$, plus radiotherapy, was begun. After eight months, a further extension of the right calcaneal lesion was observed, and a right leg amputation was performed.

Conclusions.

$\mathrm{HCC}$ is the most common liver malignan- 


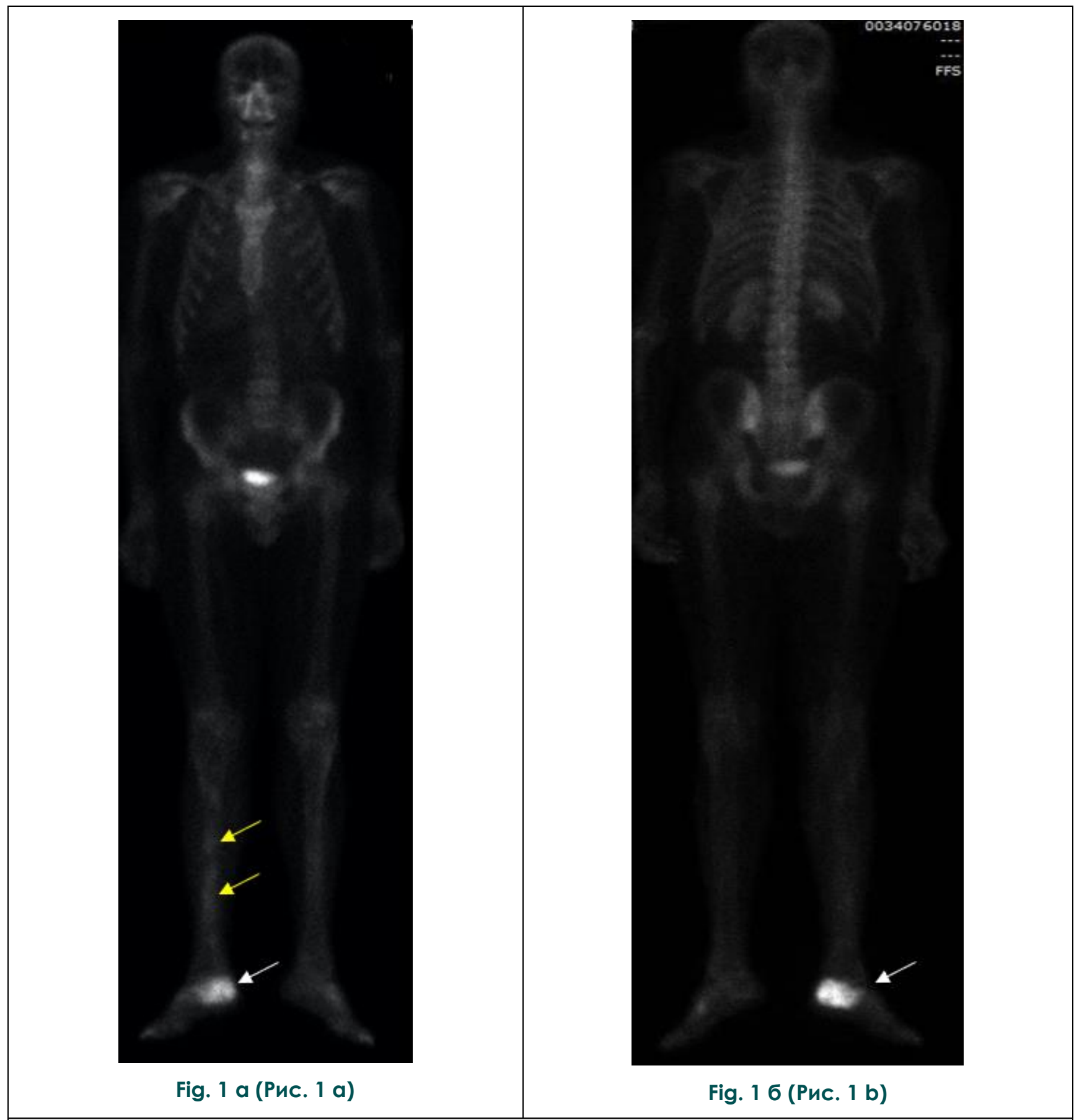

Fig. 1. Bone scintigraphy.

HCC bone metastases in the right leg and foot. Anterior (a) and posterior (b) bone scintigraphy demonstrates a radiotracer hypercaptation in the right calcaneal body (white arrow). Less evident focal hypercaptations are also detected in middle and distal portions of the right tibia (yellow arrows). No further hypercaptations were found, not even in the lumbar spine, where the patient reported chronic pain.

\section{Рис. 1. Сцинтиграфия скелета.}

Метастазы ГЦК в кости правой голени и стопы.

Передняя (а) и задняя (б) сцинтиграммы костей демонстрирует гиперфиксацию радиофармпрепарата в теле правой пяточной кости (белая стрелка). Менее выраженные очаги гиперфиксации выявляются также в средней и дистальной частях правой голени (желтые стрелки). Никаких дополнительных участков гиперфиксации обнаружено не было, даже в поясничном отделе позвоночника, где ранее отмечамись болевые ощущения. 


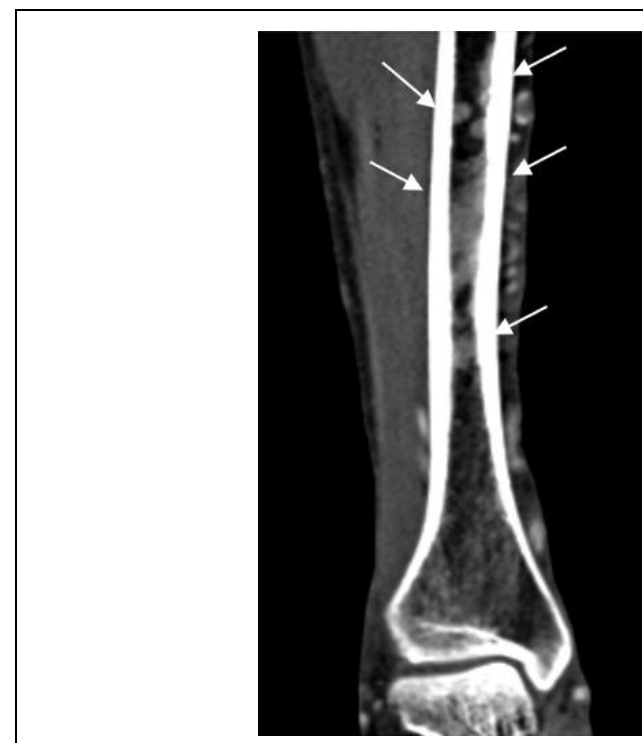

Fig. 2 a (Рис. 2 a)

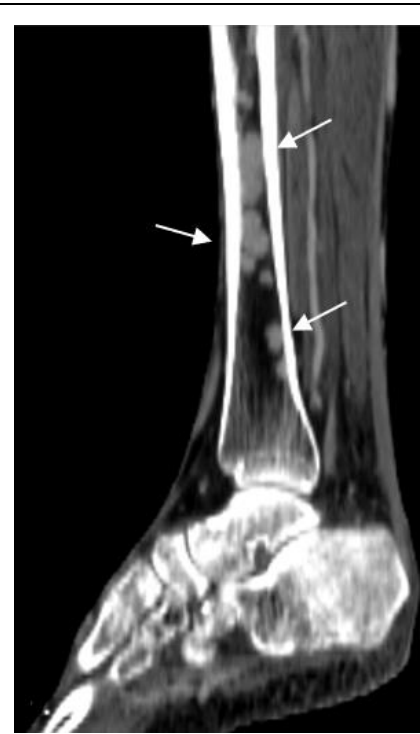

Fig. 2 б (Рис. 2 b)

Fig. 2. CT.

HCC bone metastases in the right leg. Coronal reformatted (a) and sagittal reformatted (b) postcontrast CT images of the right leg show multiple enhancing solid nodules (white arrows) in middle and distal portions of the tibial bone marrow, without cortical interruption.

Рис. 2. Кт.

Метастазы ГЦК в кости правой ноги. Коронарное (а) и сагиттальное (б) постконтрастные КТизображения правой ноги. Визуализируются множественные солидные узелки, накапливающие контрастный препарат (белые стрелки) в средней и дистальной частях костного мозга большеберцовой кости без нарушения кортикальной пластинки.

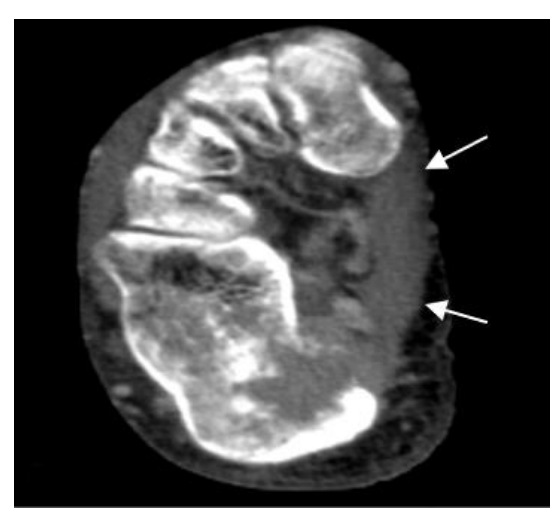

Fig. 3 a (Рис. 3 a)

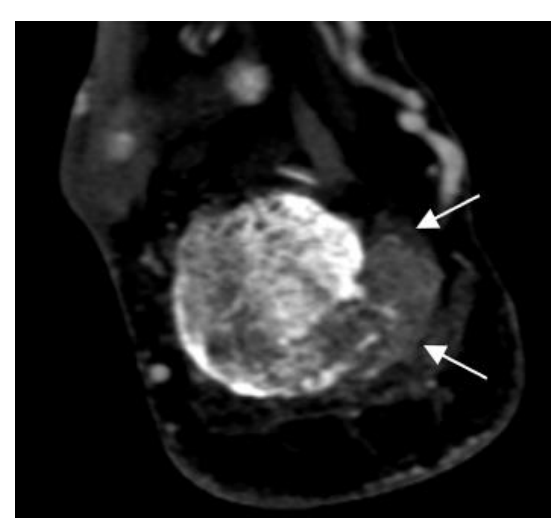

Fig. 3 b (Рис. 3 б)

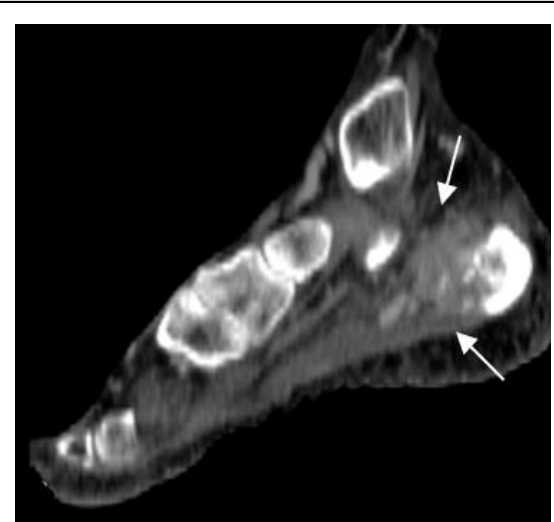

Fig. 3 с (Рис. 3 в)

Fig. 3. CT.

HCC bone metastasis in the right foot. axial (a), reformatted coronal (b) and reformatted sagittal (c) postcontrast CT images of the right foot show a 3,5 cm solid enhancing nodule, with ill-defined margins in the medial side of the calcaneus, with cortical interruption and extension to adjacent soft tissues.

Рис. 3. Кт.

Метастаз ГЦК в области правой стопы. Аксиальное (а), корональное (b) и сагиттальное (с) постконтрастные изображения КТ правой стопы. Визуализируется солидный узел, накапливающий контрастный препарат, размером 3,5 см, с нечеткими контурами по медиальной стороне пяточной кости, с нарушением кортикальной пластинки и распространением на прилежащие мягкие ткани. 


\section{RUSSIAN ELECTRONIC JOURNAL OF RADIOLOGY}

cy, but usually intrahepatic metastases are observed, due to dissemination through portal vein, which leads to an intrahepatic localization $[1,4]$. On the other end, dissemination through intrahepatic veins is rare and usually occurs later, causing metastases in distant organs, and the most common sites are: lungs and adrenal glands [5].

In adult age and in the elderly, chronic hindfoot pain is mainly caused by degenerative changes, which should be excluded [6]. Systemic causes such as osteoarthritis and gout should be also excluded; secondary lesions and tuberculosis are considered rare causes [6].

As for HCC, most common sites of metastases are: lungs and adrenal glands while bones are not frequent sites of HCC metastases [5]. Usually the bones involved are vertebrae, ribs, pelvis, and femurs; there is only one case report in literature that has described tibiofibular HCC metastasis [7]. No HCC metastases in the calcaneus have yet been described [8].

A first assessment with foot radiograph is usually performed, checking for osteophytosis and other bone anomalies [9].

$\mathrm{CT}$ is required for a more precise assessment of a bone lesion, to evaluate cortical interruption and extra-osseous extension [3].

Bone scintigraphy can contribute in the assessment of diffuse benign and malignant bone disease, with a precise detection of lesions with bone tropism [10].

\section{References:}

1. Kulik L., El-Serag H.B. Epidemiology and management of hepatocellular carcinoma. Gastroenterology. 2019; 156 (2): 477-491.e1.

2. Forner A., Reig M., Bruix J. Hepatocellular carcinoma. Lancet. 2018; 391 (10127): 1301-1314.

3. Hennedige T. Advances in computed tomography and magnetic resonance imaging of hepatocellular carcinoma. World J Gastroenterol. 2016; 22 (1): 205.

4. Mitsunobu M., Toyosaka A., Oriyama T., Okamoto E., Nakao N. Intrahepatic metastases in hepatocellular carcinoma: the role of the portal vein as an efferent vessel. Clin Exp Metastasis. 1996; 14 (6): 520-529.

5. Senthilnathan S., Memon K., Lewandowski R.J., et al. Extrahepatic metastases occur in a minority of hepatocellular carcinoma patients treated with locoregional therapies: Analyzing patterns of progression in 285 patients. Hepatology. 2012; 55 (5): 1432-1442.
Magnetic resonance is also useful in the evaluation of a bone lesion, assessing texture features which can help in identification of primary bone tumors, and in the evaluation of soft tissue, checking for edematous changes and infiltration [3].

In our case, foot radiograph was avoided because the chronic hindfoot pain with the high alpha-fetoprotein levels raised the suspicion of bone metastases.

Bone scintigraphy revealed a radiotracer hypercaptation in the right tibia and calcaneus. Bone CT showed multiple enhancing solid nodules compatible with metastases in the right tibia and a big tumor lesion in the medial side of the calcaneus with interruption of the cortical bone and extension in the soft tissues. A biopsy confirmed that it was an HCC metastasis.

In conclusion, in a patient with HCC and chronic hindfoot pain, with increase of alphafetoprotein levels, the possibility of a distant metastasis should be taken in account, as in our case, even though it is a rare cause.

\section{Ethics statement.}

This study received approval from Ethical Committee of Foundation IRCCS Ca' Granda Maggiore Policlinico Hospital and the patient provided written informed consent for publication of his case details and accompanying images.
6. Menz H.B. Chronic foot pain in older people. Maturitas. 2016; 91: 110-114.

7. Bhatia R., Ravulapati S., Befeler A., Dombrowski J., Gadani S., Poddar N. Hepatocellular carcinoma with bone metastases: Incidence, prognostic significance, and managementsingle-center experience. $J$ Gastrointest Cancer. 2017; 48 (4): 321-325.

8. Parashar K., Pandit-Taskar N. Foot and ankle hepatocellular carcinoma metastasis. Clin Nucl Med. 2016; 41 (1): 69-71. 9. Thomas M.J., Peat G., Rathod T., et al. The epidemiology of symptomatic midfoot osteoarthritis in community-dwelling older adults: cross-sectional findings from the clinical assessment study of the foot. Arthritis Res Ther. 2015;17 (1): 178.

10. Van den Wyngaert T., Strobel K., Kampen W.U., et al. The EANM practice guidelines for bone scintigraphy. Eur $J$ Nucl Med Mol Imaging. 2016; 43 (9): 1723-1738. 